\title{
Creatinine and Renal Function in Children
}

\author{
Lydia Kristanti Hartono Kosnadi
}

\begin{abstract}
Abstrak
Pada umumnya laju sintesis kreatinin tetap dan kadar kreatinin plasma $\left(P_{\mathrm{kr}}\right)$ mencerminkan laju eliminasinya melalui ginjal. Tiap anak sakit ginjal perlu diukur faal ginjalnya untuk mengetahui berapa jauh penyakit itu telah merusak jaringannya. Tujuan penelitian ini ialah mengukur $P_{\mathbf{k r}}$ dan faal ginjal atau laju filtrasi glomerulus $(L F G)$ yang dinyatakan oleh kliren inulin $\left(K_{\mathrm{in}}\right)$ dan kliren kreatinin $\left(K_{\mathbf{k}}\right)$ pada anak sakit ginjal, dan mengetahui bagaimana hubungan antara keduanya. Pada studi belah-lintang ini besar sampel dihitung dengan Sampel Tunggal untuk Estimasi Proporsi Suatu Populasi, dan analisis data dilakukan dengan Korelasi Produk Momen Pearson. Telah dilakukan pengukuran simultan $K_{\text {in }}$ dan $K_{\mathbf{k r}} 112$ anak dari bulan Maret 1991 sampai dengan Juli 1993. Hasil studi ini menunjukkan bahwa antara $P k r$ dengan $L F G$ yang dinyatakan oleh $K_{\text {in }}$ dan $K_{\mathrm{kr}}$ terdapat korelasi negatif hiperbolik pada semua anak dengan faal ginjal campuran (normal dan terganggu): $P_{\mathrm{kr}}=4,34-0,03 K_{\mathrm{in}}(r=-0,58 ; p<0,001 ; N=112)$ dan $P_{\mathrm{kr}}=4,72-0,03 K_{\mathrm{kr}}(r=-0,60$; $p<0,001 ; N=112$ ).
\end{abstract}

\begin{abstract}
In most clinical conditions, the rate of creatinine synthesis remains constant and its plasma concentration reflects the rate of renal elimination. To know how far the kidneys have been damaged the renal function in children suffering from renal diseases must be measured. The aim of this study was to measure plasma creatinine concentrations $\left(P_{\mathrm{cr}}\right)$ and renal function or glomerular filtration rates $(G F R)$ expressed by inulin clearance $\left(C_{\mathrm{in}}\right)$ and cleatinine clearance $\left(C_{\mathrm{cr}}\right)$ in children suffering from renal diseases, and to know how would be the correlation between them. In this cross-sectional study sample size was estimated by the one-sample for estimating the population proportion, and data analyzing was done by the Pearson Product Moment Correlation. Simultaneous measurements of $C_{\mathrm{in}}$ and $C_{\mathrm{cr}}$ levels in 112 children were done over the period from March 1991 to July 1993. Result of this study showed there was a hyperbolic negative correlation between $P_{\mathrm{cr}}$ and GFR in all children with mixed (normal and decreased) renal functions $: P_{\mathrm{cr}}=4.34-0,03 C_{\mathrm{in}}$ $(r=-0.58 ; p<0.001 ; N=112)$ and $P_{\mathrm{cr}}=4.72-0.03 C_{\mathrm{cr}}(r=-0.60 ; p<0.001 ; N=112)$
\end{abstract}

Keywords: Plasma creatinine, Inulin and creatinine clearances, Children

\section{INTRODUCTION}

Creatinine, a product of creatine and phosphocreatine metabolism, is synthesized predominantly in the skeletal muscles. Creatinine is exclusively excreted through the kidneys, predominantly by the process of glomerular filtration and to a lesser extent by tubular secretion. In most clinical conditions, the rate of creatinine synthesis remains constant and its plasma concentration reflects the rate of renal elimination. ${ }^{1}$

The importance of measuring of renal function or GFR in children suffering from renal diseases is to know how far the kidneys have been damaged, ${ }^{2}$ as GFR is the aspect of renal function that correlated closely with

Division of Pediatric Nephrology, Department of Child Health, Medical School, Diponegoro University/Dr. Kariadi Hospital, Semarang, Indonesia ability of the kidneys to maintain the composition of the body fluids within the ranges compatible with life. ${ }^{3}$ Three methods to measure GFR are inulin clearance $\left(\mathrm{C}_{\mathrm{in}}\right)$ (gold standard), radioisotopic clearance $\left(\mathrm{C}_{\mathrm{ra}}\right)(\mathrm{ac}-$ curate) and $\mathrm{C}_{\mathrm{cr}}$ (sufficiently accurate), ${ }^{4,5}$ There are limitations for the utility of these clearance methods. $\mathrm{C}_{\text {in }}$ takes a long time to perform, the procedure is difficult, very expensive, and it is not practical to use it routinely in the clinic. $\mathrm{C}_{\mathrm{ra}}$ is available only in a well equipped and expensive health centre. In clinical practice GFR is measured by endogenous $\mathrm{C}_{\mathrm{cr} .}{ }^{5}$

The aim of this study was to measure the levels of plasma creatinine concentration $\left(\mathrm{P}_{\mathrm{cr}}\right)$ dan GFR, expressed by $\mathrm{C}_{\mathrm{in}}$ and $\mathrm{C}_{\mathrm{cr}}$ in children suffering from renal diseases, and to know how would be the correlation between them.

This study needed to be investigated because the pediatric renal disease in our country comprised about 
$2,3 \%$ of the hospitalized children, of which the frequency of renal failure was about $25 \%{ }^{6}$ And every child in the community could suffer from renal disease irrespective of the socioeconomical class, education, in urban or rural area, and others.

\section{MATERIALS AND METHODS}

The procedures of this study were in accord with the "Pedoman Etik Penelitian Kedokteran Indonesia". This cross-sectional study was performed in children suffering from renal diseases, admitted in the hospitals in Semarang, boys and girls, aged 2-14 years. During the first two years of life, GFG continues to increase and, based on boy surface area, reaches adult levels between one to two years of age. ${ }^{8}$ Despite the increase in $P_{\text {er }}$ GFR corrected for body surface area remains nearly constant and does not differ significantly between male and female subjects. ${ }^{9}$ The sample size was estimated by the one-sample for estimating the population proportion. ${ }^{10}$

Measurements of the standard $\mathrm{C}_{\text {in }}{ }^{11}$ and the conventional endogenous $\mathrm{C}_{\mathrm{cr}}{ }^{5}$ were undertaken simultaneously. A solution of $10 \%$ inulin as reagent was made by the method of CAS 9005-80-5. ${ }^{12}$ Inulin concentration in plasma $\left(\mathrm{P}_{\mathrm{in}}\right)(\mathrm{mg} \%)$ and in urine $\left(\mathrm{U}_{\text {in }}\right)(\mathrm{mg} \%)$ were assayed by UV-method for D-fructose. ${ }^{13} \mathrm{P}_{\mathrm{cr}}(\mathrm{mg} \%)$ and creatinine concentration in urine $\left(\mathrm{U}_{\mathrm{cr}}\right)(\mathrm{mg} \%)$ were assayed by Abbott Spectrum Autoanalyzer. Urine flow was $\mathrm{V} \mathrm{ml}$ per minute. Renal clearance formula of standar $C_{\text {in }}$ is $\left[\left(U_{\text {in }} \times \mathrm{V}\right): \mathrm{P}_{\text {in }}\right] \mathrm{ml} / \mathrm{min} / 1.73 \mathrm{~m}^{2}$ and that of conventional endogenous $\mathrm{C}_{\mathrm{cr}}$ is $\left[\left(\mathrm{U}_{\mathrm{cr}} \mathrm{X} \mathrm{V}\right): \mathrm{P}_{\mathrm{cr}}\right]$ $\mathrm{ml} / \mathrm{min} / 1.73 \mathrm{~m}^{2}$. Data analysis was done by the Pearson Product Moment Correlation. ${ }^{14}$

This study was got its Ethical Clearance approved by the Research Team of Medical Faculty of Diponegoro University / Dr Kariadi General Hospital in Semarang. Written informed consent have been obtained from all the pediatric patients' parents.

\section{RESULTS}

Simultaneous measurements of standard $C_{i n}$ and conventional endogenous $C_{c r}$ were performed in 112 children suffering from renal diseases, admitted in the Children Wards of Dr Kariadi General Hospital, Telogorejo Hospital and St. Elisabeth Hospital in Semarang, age 2-14 years, consisted of $68(60.7 \%)$ boys and 44 (39.3\%), over the period from March 1991 to July 1993 (29 months). Range of the standard $C_{i n}$ was from 3 to $177 \mathrm{ml} / \mathrm{min} / 1.73 \mathrm{~m}^{2}$ and of the conven- tional endogenous $C_{c r}$ was from 4 to $196 \mathrm{ml} / \mathrm{min} / 1.73$ $\mathrm{m}^{2}$. Range of $P_{\mathrm{cr}}$ was from 0.23 to $15.83 \mathrm{mg} \%$.

There was a hyperbolic negative correlation between $P_{c r}$ and GFR expressed by $C_{i n}$ and $C_{c r}$ in children with mixed renal functions (normal and decreased) showed by the regression equations : $P_{c r}=4.34-0.03 C_{i n}(r=$ -0.58; $\mathrm{p} 0.001 ; \mathrm{N}=112$ ) (Figure 1) and $\mathrm{P}_{\mathrm{cr}}=4.72$ $0.03 C_{c r}(r=-0.60 ; p<0.001 ; N=112)$ (Figure 2).

\section{DISCUSSION}

Hyperbola in Figure 1 showed the correlation between $\mathrm{P}_{\mathrm{cr}}$ and $\mathrm{C}_{\mathrm{in}}$ was in accord with that reported by Guignard et al $^{15}$ and that in Figure 2 showed the correlation between $\mathrm{P}_{\mathrm{cr}}$ and $\mathrm{C}_{\mathrm{cr}}$, was in accord with that reported by Shemesh et al. ${ }^{16}$ Elevated $P_{c r}$ denotes diminished renal clearance and a decline in GFR. As it apparent from Figure 1-2 the relationship between $P_{c r}$ and GFR were not linear. ${ }^{1}$ These hyperbole curves were caused by the different GFR decrements to attain a new $\mathrm{P}_{\mathrm{cr}}$ steady states between acute renal failure and acute on chronic renal failure. To detect $1 \mathrm{mg} \%$ rise in $\mathrm{P}_{\text {cr }}$ the former required at least $50 \%$ but the later required just $15 \%$ decrement from the initial GFR. ${ }^{17,18}$ During steady state, it can be seen that only GFR less than $50 \%$ of normal would be diagnosed as abnormal using $P_{c r}$ alone. Due to the relatively large range of normal values, the predictive value of individual $P_{c r}$ is limited. Serial measurements of $P_{c r}$ improve its usefulness. $1,4,15$

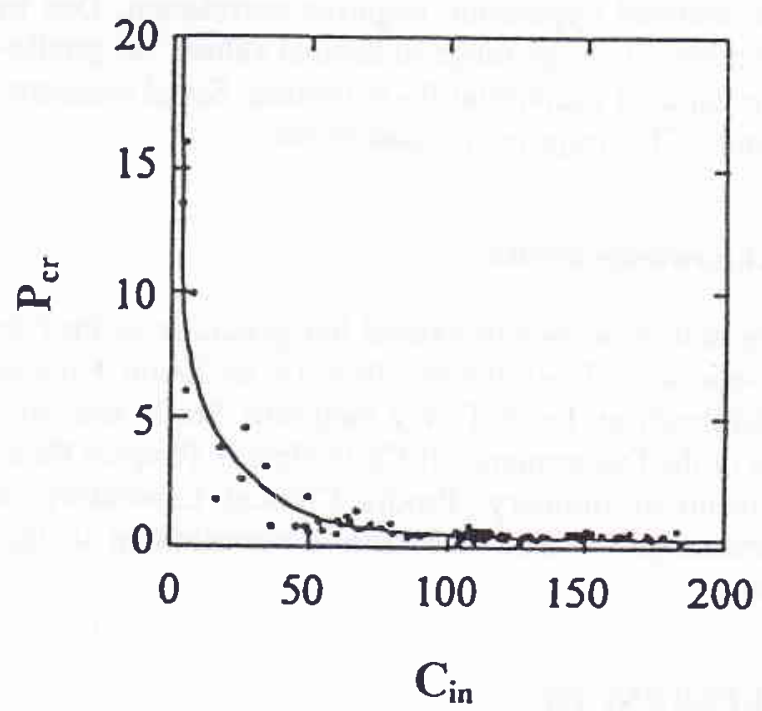

Figure 1. Hyperbolic negative correlation between plasma creatinine concentration $\left(P_{c r}\right)$ and renal function (Normal and Abnormal) expressed by inulin clearance $\left(C_{i n}\right)$ in 112 children aged 2-14 years :

$P_{c r}=4.34-0.03 C_{\text {in }}(r=-0.58 ; p<0.001 ; N=112)$ 


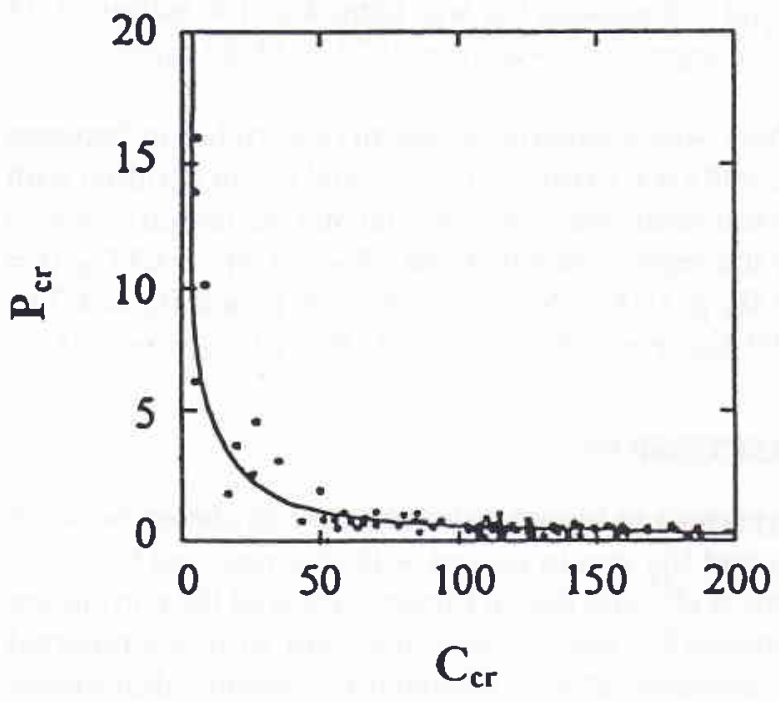

Figure 2. Hyperbolic negative correlation between plasma creatinine concentration $\left(P_{c_{r}}\right)$ and renal function (normal and abnormal) expressed by creatinine clearance $\left(C_{c r}\right)$ in 112 children aged $2-14$ years :

$P_{c r}=4.72-0.03 C_{c r}(r=-0.60 ; p<0.001 ; N=112)$

\section{CONCLUSIONS}

In children with normal and decreased renal functions, plasma creatinine concentrations and glomerular filtration rates, expressed by inulin and creatinine clearances, showed hyperbolic negative correlation. Due to the relatively large range of normal values, the predictive value of individual $P_{c r}$ is limited. Serial measurements of $\mathrm{P}_{\mathrm{cr}}$ improve its usefulness.

\section{Acknowledgements}

The author wishes to extend her gratitude to Prof $d r$ Moeljono S Trastotenojo, Prof Dr dr Imam Parsudi Abdulrochim, Dr dr Tonny Sadjimin, Staffs and Nurses of the Departments of Child Health, Phapros Pharmaceutical Industry, Prodia Clinical Laboratory in Semarang, for their substantive contribution to this study.

\section{REFERENCES}

1. Kher KK. Evaluation of Renal Functions. In : Kher KK, Makker SP, editors. Clinical Pediatric Nephrology, 1st ed. New York : McGraw-Hill, 1992:1-22.
2. van Collenburg J. Aspecten van (Gescheiden) Nier Functie Onderzoek bij Kinderen (Proefschrift). Rotterdam : Erasmus Universiteit, 1980.

3. Liftchift MD. The Evaluation of Renal Function. In : Forland M, editor. Nephrology. Bern : Huber Publishers, 1977:3442.

4. Taylor CM. Assessment of Glomerular Filtration Rate. In : Postlethwaite RJ, editor. Clinical Paediatric Nephrology. 2nd ed. Oxford : Butterworth Heinemann, 1994:89-100.

5. Koeppen BM, Stanton BA. Renal Physiology. 1st ed. St Louis : Mosby Year Book, 1992.

6. Lydia-Kosnadi, Tambunan T, Wila Wirya IGN, Alatas H, Rauf S, Singadipura B, Sekarwana N, Bahrun D, Damanik M, Suryantoro P, Komang Kari I. Pola Penyakit Ginjal Anak di Indonesia - Studi Kolaboratif. Dalam : Lydia Kosnadi, Santoso Soeroso, Hariyono Suyitno, editor. Disajikan pada Simposium Nasional IV Nefrologi Anak. Fakultas Kedokteran Universitas Diponegoro - Ikatan Dokter Anak Indonesia Jateng, Semarang, Juni 23-24, 1989.

7. Sri Oemijati, Setiabudy S, Budiyanto A. Pedoman Etik Penelitian Kedokteran Indonesia. Jakarta : Fakultas Kedokteran Universitas Indonesia, 1987.

8. Moore ES, Aronson AJ, Northrup TE. The Assessment of Renal Function. In : Postlethwaite RJ, editor. Clinical Paediatric Nephrology. 1st ed. Bristol : Wright, 1986:40411.

9. Schwartz GJ, Brion LP, Spitzer A. The Use of Plasma Creatinine for Estimating Glomerular Filtration Rate in Infants, Children and Adolescents. Pediatr Clin North Amer 1987; 34 (3):571- 90.

10. Madiyono B, Moeslichan S, Sastroasmoro S, Budiman I, Purwanto SH. Perkiraan Besar Sampel. Dalam : Sastroasmoro S, Ismael S, editor. Dasar-Dasar Metodologi Penelitian Klinis. Jakarta : Binarupa Aksara 1985:187-212.

11. Bohlin AB. Clinical Course and Renal Function in Minimal Change Nephrotic Syndrome. Acta Paediatr Scan 1984; 73:631-6.

12. Reynold EF, Prasad AB. Inulin. In : Martindale - The Extra Pharmacopoeia. 28th ed. London : The Pharmaceutical Press, 1982 : 520.

13. Boehringer Mannheim Biochemical Analysis, Food Analysis. D- Glucose/D-Fructose, 1990.

14. Munro BH, Visintainer MA, Page EB. Statistical Methods for Health Care Research. Philadelphia : Lippincott, 1986:86-126.

15. Guignard JP, Torrado A, Feldman H, Gautier F. Assessment of Glomerular Filtration Rate in Children. Helv Paediat Acta $1980 ; 35: 437-47$

16. Shemesh $\mathrm{O}$, Golbets $\mathrm{H}$, Kriss JP. Limitations of Creatinine as a Filtration Marker in Glomerulopathic Patients. Kidney Int $1985 ; 28: 830-8$.

17. Kassiger JP, Harnington JT. Laboratory Evaluation of Renal Function. In : Schrier RW, Gottschalk CW, editors. Diseases of the Kidney. 4th ed. Vol I. Boston : Little Brown, 1988 : 393-441.

18. Brezis M, Rosen, Epstein FH. Acute Renal Failure. In : Brenner BM, Rector FCJr, editors. The Kidneys. 4th ed. Vol I. Philadelphia : Sauders, 1991:993-1061. 